\title{
Karavayskaya O.S. Development of Russian terminology science
}

Omsk State Transport University (Russia, Omsk)

doi: $10.18411 / \mathrm{j}-02-2021-267$

idsp: ljournal-02-2021-267

\section{Abstract}

The article examines the main stages in the development of Russian terminology science. The two main schools of terminology are showed. An overview of the main approaches to the study of the term is made, and prominent scientists-terminologists are presented. In the conclusion, the current state of Russian terminology is noted.

Key words: anthropolinguistics, classification approach, cognitive linguistics, ethnolinguistics, ethnopsycholinguistics, functional approach, sociolinguistic aspect terminology, terminology science.

The development of science and technology inevitably entails the emergence of new terms, and sometimes entire terminologies. This article examines the main stages in the development of Russian terminology science.

Nowadays, in connection with the growth of scientific and technological progress and the modernization of science, education and production, the role of special vocabulary is increasing. The terms are the regulator of professional activity and the most important means of scientific communication.

The term is a linguistic unit that has a special meaning and functions, as a rule, in the professional sphere.

As noted by L.B. Tkacheva, «almost all the achievements of scientific and technological progress are reflected in the languages of the world. This manifested itself, first of all, in an avalanche-like stream of new terms, conveying new concepts, phenomena and signs brought to life both by the development of long-existing branches of knowledge and the emergence of newly created fields of science and technology» [1, p. 23].

The problems of terminology constantly attract the attention of both foreign and domestic linguists. Among foreign researchers, it is worth noting E. Wuster, a representative of the Viennese terminological school, whose tasks included work on streamlining and standardizing all existing scientific and technical terminology. One of the achievements of the representatives of this school is the holding of the first international conferences on terminology, cooperation both with representatives of other nations and other fields of knowledge.

Another school of terminology - Prague - is also considered the main, basic school. Yu.N. Marchuk states that «...it is based on the linguistic theory of the Prague school of Trubetskoy and other scientists who laid the foundation for functional grammar» [2, p. 29].

Also, the most notable contribution to the development of terminology was made by such foreign scientists as E. Allan, R.V. Brown, G. Rondo, T. Savory, H. Felber and V. Fleischer.

In our country, research began in the 1930s. The starting point is considered to be 1931, when D.S. Lotte published the first article on the problems of unification and standardization of technical terminology. D.S. Lotte dealt with the issues of standardization of terms, the problems of the emergence of new terms, the creation of conceptual and terminological systems and the problems of translating scientific and technical terms. Also, the scientist considered ways of borrowing terms. 
D.S. Lotte is considered the founder of the Russian school of terminology. The main provisions of his theoretical teachings were expressed in such works as «Issues of borrowing and ordering foreign terms and term elements», «Brief forms of scientific and technical terms», «Some fundamental issues of selection and construction of scientific and technical terms», «Fundamentals of building scientific and technical terminology: Questions of theory and methodology», "The next tasks of technical terminology». Even now, research is being conducted in our country based on the works of D.S. Lotte.

The pre-war stage (1935-1940) in the development of domestic terminology is also associated with the name of the famous Soviet terminologist E.K. Dresen. According to Yu. $\mathrm{N}$. Marchuk, «...he was an engineer by training and spent a lot of work collecting and systematizing terminology in various fields of science and technology. Before World War II, he worked in broad international cooperation. His works served as the basis for fundamental research on terminology in the USSR» [2, p 29].

The basis of Dresden's research is the concept of the accuracy of a term, that is, the presence of a term with a clear and most complete, definite concept. D.S. Lotte and E.K. Dresen are the founders of the classification (normative, static) approach to terminology. Presenting such requirements to the term as absolute and relative unambiguity, accuracy, consistency, brevity, lack of synonyms, correspondence between literal and real meanings, simplicity and clarity, and others, the nomination (ordering) of scientific and technical terminology was made.

The second approach to studying terminology is linguistic or functional. Its main ideas are expressed in the classic articles by G.O. Vinokura «On some phenomena of word formation in Russian technical terminology» (1939) and «Grammatical observations in the field of technical terminology» (1939), which consider the definition of a term, description of its properties and functions.

Like G.O. Vinokur, A.A. Reformatsky made a significant contribution to the development of Russian terminology. He introduced for the first time in 1947 in the textbook on linguistics the section «Terminology», where he considered the questions belonging of a term to a certain terminology, monosemantisation of words in the transition to the category of terms, lack of synonyms in terminology, lack of expression and emotionality in the term, and others. Unlike representatives of the normative approach, the followers of the functional point of view argue that the boundaries between terminology and common vocabulary are arbitrary.

S.V. Grinev-Grinevich emphasizes that «the border between terminological and common vocabulary is unstable and has not a historical, but a functional character, both the process of converting terms into common words and the use of everyday vocabulary for the formation of terminologies is constantly taking place» [3, p. 29].

N.P. Kuzkin takes an extreme position, stating that «neither in form nor in content and it is impossible to find a significant difference between the word of common, non-special vocabulary and the word of terminological vocabulary. The real, objective difference between the two types of these words is, in essence, an extra-linguistic difference. If the word of common, non-special vocabulary is related to a well-known object, then the word of terminological vocabulary is related to a specific object, known only to a limited circle of specialists. There is no other difference between these types of words» [4, p. 145].

Within the framework of the functional approach, such scientists as A.F. Lesokhin, P.A. Florensky, M.I. Volodin, V.P. Danilenko, V.M. Leichik worked.

Among the well-known representatives of Russian terminology science are such scientists as O.S. Akhmanova, V.V. Vinogradov, S. V. Grinev, V. A. Tatarinov, on the basis of whose works all modern research is conducted. 
Since the 1970s of the 20th century, interdisciplinary research has become widespread. In linguistics, they began to assign a special role to extralinguistic factors, as a result of which terminology began to be studied in the sociolinguistic aspect. Yu.D. Desheriev believes that such studies «require deep and versatile knowledge in the field of linguistics, sociology, philosophy, history, culture, as well as appropriate acquaintance with those spheres of social life in which the studied languages are used» [5, p. 9].

Also, such areas of linguistic research as cultural linguistics, ethnolinguistics, ethnopsycholinguistics, anthropolinguistics, and cognitive linguistics were formed and developed. A number of scientists (V.V. Nalimov, G. Ryle, S.V. Sokolovsky) note the difficulties of interdisciplinary research associated with specific sets of knowledge in a scientist of a certain direction.

Cognitive linguistics is now widespread. Cognitive linguistics is a direction in linguistics that arose in the 70s - 80s of the XX century and is actively developing at the present time. In Russian linguistics, such scientists as O.S. Akhmanova, E. G. Belyaevskaya, V. M. Volodina, E.S. Kubryakova, A.F. Losev, R.G. Piotrovsky follow cognitive approach.

One of the methods for studying terminological systems in the cognitive approach is frame analysis. Since there are some structures of knowledge (mental entities) in human consciousness, such a structural formation as a frame can be used to describe them.

The founder of the scientific school «cognitive terminology» is E.I. Golovanov. In 1993, the Russian terminological society «RossTerm» was created in Russia on the initiative of V.A. Tatarinov. Its tasks include the coordination of scientific research in the field of terminology and methods of teaching languages for special purposes, assistance in the creation of terminological dictionaries and textbooks, the organization of scientific conferences and seminars, the implementation of scientific relations with foreign colleagues and terminological organizations. In Russia, terminology standardization programs are carried out at the Moscow Scientific Research Institute for Comprehensive Information on Standardization and Quality. It publishes the journal «Scientific and Technical Terminology».

The problems of unification of terminology in natural and technical sciences are faced by the Committee of Scientific and Technical Terminology of the Russian Academy of Sciences. The Vienna-based International Center for Information on Terminology (Infoterm) and the International Organization for the Unification of Terminological Neologisms (Warsaw), which publishes the journal Neoterm, are major international organizations coordinating international research in terminology. International standards are developed by the International Organization for Standardization, the International Electrotechnical Commission and other international institutions.

Despite many opinions on the importance of a particular function of a term, it should be noted that the approach that a scientist chooses to analyze terms depends on the focus of research on a particular function.

\section{$* * *$}

1. Tkacheva L. B. Basic laws of English terminology. / L. B. Tkacheva - Tomsk: Publishing house of Vol. University, 1987 . - 200 p.

2. Marchuk Yu.N. Fundamentals of terminography. Toolkit. / Yu.N. Marchuk - M.: TsII MGU, 1992 . 76 p.

3. Grinev-Grinevich S.V. Introduction to terminology. / S.V. Grinev-Grinevich - Moscow: Mosk. Lyceum, $1993 .-309$ p.

4. Kuzkin N. P. On the question of the essence of the term // Bulletin of Leningrad State University, N 20, no. 4.L., 1962.S. 140-141.

5. Desheriev Yu.D. Language in a developed socialist society. / Yu.D. Desheriev - Moscow: Nauka, 1983. $-256 \mathrm{p}$. 